\title{
Land of cemetery: funereal images in the poetry of Musa Idris Okpanachi
}

\section{Uchechukwu Peter Umezurike}

Uchechukwu Peter Umezurike is currently a PhD student in the Department of English and Film Studies at the University of Alberta.

Email: umezurik@ualberta.ca

DOI: dx.doi.org/10.17159/2309-9070/tvl.v.55i2.1325

\section{Land of cemetery: funereal images in the poetry of Musa Idris Okpanachi}

This paper focuses on Musa Idris Okpanachi's poetry: The Eaters of the Living (2007), From the Margins of Paradise (2012), and Music of the Dead (2016). Nigeria, even after the military had relinquished power over a decade ago, is still faced with the issues that provoked the trope of protest in much of the poetry published between the mid-eighties and late nineties. Okpanachi's poetry revisits these issues, demonstrating that democracy has been no less horrifying than military despotism. Dark, haunting images of blood, corpses, and cemetery recur in all three collections, depicting the regularity of death in the nation. I argue that Okpanachi employs funereal imagery to comment on the state's morbid relationship with its citizenry. The Nigerian state is represented as murderous, so death fulfills its political objective. I conclude that although 0 kpanachi articulates a cynical commentary on postcolonial Nigeria, he marshals his creative energies to illuminate the political moment of his time. Keywords: democracy, funereal imagery, necropolitics, Nigerian literature, Musa Idris Okpanachi.

\section{Introduction}

Nigerian creative writers tend to employ poetry as a cultural medium to document historic political moments. Nigeria's current democracy is over seventeen years old, and it presents a theme definite enough to provide stimulus for poetic exposition. Not much contemporary poetry has interrogated the present political moment with the same fervour and urgency displayed by the previous generations of poets. In addition, compared to the volume of critical studies on prose, poetry criticism in Nigeria is still paltry. It is not surprising to note that scholarship on the poetry of Musa Idris Okpanachi, a university scholar and award-winning poet with three published poetry collections to his credit, is little. This paper aims to stimulate interest in Okpanachi's poetry and to examine his artistic vision within the ethos of social commitment, while foregrounding his contribution to the discourse of democratic struggle.

Nigeria remains one of the countries in the world where death seems to occur quite regularly, even though it has not been at war since 1970, when the civil war ended. Thousands have died avoidably since the military handed over power to a civilian administration in 1999. I use the term "avoidably" because the government tends to ignore certain contentious issues of a sectional and religious nature that ultimately snowball into sporadic and mass killings. The menace of the Fulani herdsmen, for 
instance, has been treated casually by the federal authorities. Why has democracy transformed this oil-rich nation into a "land of cemetery"? This is the question Musa Idris Okpanachi reflects on in his poetry.

A question that I examine in this paper is: What might Okpanachi's preoccupation with images of blood, corpses, graves, and cemetery tell us about his vision and his homeland? To answer this question, I begin by examining the funereal imagery in the texts. Next, I point out the significance of this imagery within the context of social commitment. I read Okpanachi's poetry as a stand against power. Evident in the poetry is the tone of marked disenchantment with the body politic, but this feeling is informed by the poet's appreciation of the functionality of art. Using Achille Mbembe's concept of necropolitics, I argue that Okpanachi employs funereal imagery to comment on the state's morbid relationship with its citizenry. Okpanachi represents the Nigerian state as murderous. Generally, death is perceived as a social issue, but to Okpanachi, it is political, its means legitimated by an operative (il)logic of violence. Death, therefore, fulfils a necessary objective. By utilising satiric and hyperbolic elements, and limpid diction interspersed with sepulchral images, Okpanachi calls attention to the disposability of human life. He decries the degeneration indicative of abysmal political leadership, while articulating social concerns and deprecating the political elite for their treachery and despoliation of the citizenry. I conclude that although Okpanachi articulates a cynical commentary on postcolonial Nigeria, he marshals his creative energies to illuminate the political moment of his time.

\section{Tradition, despotism, and dissidence}

Military rule in Nigeria officially ended on 29 May 1999, a historic moment that heralded the restoration of democracy. Prior to 1999, the presidential election, having been held on 12 June 1993, was annulled on 23 June 1993 by General Ibrahim Babaginda, then military head of state, in rather controversial circumstances. This action, ill-timed and divisive as it was, not only terminated the Third Republic but also threatened national unity. The consequent denunciation of the military action was vocal and sustained at the time, though such activism routinely culminated in opponents of the junta being rounded up, incarcerated, or even eliminated. This political moment, as Isidore Diala observes, nurtured the explosion of "anti-military poetry" (2) in the Nigerian literary tradition. In a similar vein, Olaniyi Okunoye has argued that the military rule was a catalyst for the growth of Nigerian poetry. He chronicles the way Nigerian poetry, given impetus by the failure of the military from the mid-1980s to the late 1990s, crystallised a poetics of anti-establishment (64). However, the installation of Olusegun Obasanjo, an ex-military head of state, as the president marked a return to democratic rule, inaugurating the Fourth Republic.

The independence struggle in the 1950s, the civil war in the late 1960s, and the military rule in the 1980s and 1990s, have all featured prominently in various poetic 
works by Nigerian poets. Many of these poets belong to the third generation of Nigerian literary tradition. They are so categorized because they were born in the 1960s, after the nation's independence from Britain. Notable among these poets are Ogaga Ifowodo, Maik Nwosu, Promise Okekwe, Remi Raji, Esiaba Irobi, Unoma Azuah, Chiedu Ezeanah, Toyin-Adewale, Pius Adesanmi, Obiwu, Uche Nduka, Nnimmo Bassey, Afam Akeh, Angela Nwosu, Emman Shehu, Onookome Okome, Amatoritsero Ede, Joe Ushie, Olu Oguibe, Idzia Ahmad, Obi Nwakanma, Obu Udoezo, and others.

As Chinua Achebe rightly posited in 1983, "[ $\mathrm{t}]$ he problem with Nigeria is simply and squarely a failure of leadership" (1). The abiding motif of political leadership, whose failure this generation of poets locate in the military dictatorships of General Ibrahim Badamosi Babangida (1986-93) and the late General Sani Abacha (1993-98), is central to their poetry. Aboh comments that "this generation of poets engages their poems as avenues to register their contempt with a system that makes them slaves in their own country. [...] Above all, these poets have continued to forge the link between the poets and their society; making their poems an outlet for the people's socio-political expression" (2).

Okpanachi belongs to this third generation, in part by age and in part because his poetics evinces a similar consistency in the demonstration of commitment to tradition, thereby continuing the trope of dissidence in the Nigerian poetic tradition. Romanus Egudu, Egya Sule, and Olaronke Temiloluwa Onibonukuta have examined Musa Idris Okpanachi's poetry. Romanus Aboh examines the significance of modal verbs on the speaker's attitude in the poetry of four Nigerian poets. In undertaking a linguistic analysis of Okpanachi's poetry collection The Eaters of the Living, he points out the way the poet unflinchingly engages issues of national weight. Egya Sule identifies the poet as representative of "the oppressed people of the country", against the "despot and her cohorts" ("Poetry as dialogue: A Reading of Recent Anglophone Nigerian Poetry" 85). In another essay, "Imagining Beast: Images of the Oppressor in Recent Nigerian Poetry in English," Sule surveys a representative sample of Nigerian poems and highlights the usage of bestial imagery in Okpanachi's poems to denigrate and delegitimize the ruling class, thus revealing its inhuman tendencies.

\section{Morbidity, democracy, and (necro) poetry}

Achille Mbembe's critique of power illuminates the nexus between politics and death, and how the state has grown necropolitical in its relationship with its citizens, so as to exercise control over mortality. Although Mbembe applies his concept of necropolitics to theorize the realities of social life under colonial occupation, as experienced by the people in Israeli-controlled Palestinian territories, and in the apartheid state of South Africa, I find his concept pertinent as a framework to understanding the Nigerian state's investment in an economy of death. Sovereignty for the Nigerian state implies that it must decide who may live and who must die (see Mbembe 12-4), 
in that politics assumes the form of a "war without end" (Mbembe 23). Unsurprisingly, the police, the military, and the other state apparatuses, completely repressive in the Althuserrian sense, cease from protecting and providing security for the citizens. Rather they function as death-machines, dealing death at will, wielding the power of life and death over citizens. But citizenship in such a state approximates the status of the "living dead" (Mbembe 40), since the necropolitical state has already transformed the land into a death-world. The state apparatus, vested with the right to kill, indubitably believe that to kill is right. A perverse logic thus underpins and authorizes the economy of death, such that death becomes so commonplace the political elite appear to glory in and celebrate it.

If military despotism provided the dominant theme in much of Nigerian poetry published between the mid-1980s and 1990s, civilian misrule became the operative theme for Okpanachi's poetic ruminations. It is troubling - and very ironic-that more Nigerians have possibly been killed in various sectional, religious, and politically-motivated killings in the last 17 years of civilian administration than in the almost 30 years of military despotism. One may attribute this morbid situation to state apathy and irresolution. Okpanachi is a poet invested in the political discourse of nationhood. I now analyse selected poems in which funereal imagery recurs in The Eaters of the Living (2007), From the Margins of Paradise (2012) and Music of the Dead (2016). I shall focus primarily on the latter publication because the imagery is more pronounced in that collection than it is in the earlier collections.

Okpanachi's debut collection, The Eaters of the Living, opens with "Silence of time", a poem which, on the surface, might indicate the woebegone days of military rule, but on a closer reading will reveal that the images are synonymous with the civilian government in recent times. Considering that the poem was first published in 2007, eight years after the end of military dictatorship, its overarching imagery of "bones crushed / under the menace of boots", of "curfew, emergency", "riots on the streets", "blood flooded", "butcher", and "knife" (Eaters 10) exemplify the political realities of Nigerian democracy. However, the images of grave and cemetery make their first appearance in "We give you this country". Irony is employed in this poem for a climactic effect.

We give you this country

Because your heart desires it

Because it is where you

Spread yourself

To defile the land

To rape the maid

To change the constitution

Even from your grave. (Eaters 12, my emphasis) 
The instruments of repression forged to enforce silence populate the "Code of silence". In this poem, terror seeks "the blood of / Our youths / Who dare face/The Sun" (Eaters 13), and bravery is punishable by death. Another poem, "Manifesto", depicts the familiar terror emblematic of "an iron rule" (Eaters 14) that threatens and obliterates freedom. The ruler, rather than bringing a harvest of plenty to his people, promises a season of plagues. In fact, he brings the "gift of a coffin". Bloody images fill the following lines:

I shall bleed your head

To make you reasonable

And inject you with poisoned

Bayonet to keep you alive

$[\ldots]$

I give you the flower of my love

That will lure you to death

Here is my manifesto

Written with your blood. (Eaters 15)

A hint of cannibalism is discernible in the ruler's glee: "Welcome to the state dinner / As guests to be eaten" (Eaters 16). In the eponymous poem, "The eaters of the living", the poet uses the verb "eat" as a metaphor for the rapacity of the state. The refrain "They eat" is used as a rhetorical device to underline the consummate greed of politicians who consume "everything and everyone" (Eaters 28). The following lines illustrate this rapacity:

They eat like termites

They eat like locusts

They eat like cancer cells

\section{$[\ldots]$}

They eat the festering sores of the people

They eat our phlegm

They eat our corpses

\section{$[\ldots]$}

They eat the skin of the poor. (Eaters 28)

The poet's identification of his role as a politically conscious poet enables him to engage with issues that excoriate as well as indict the necropolitical state. Poems such 
as "The mirror" and "The spectators" reiterate the images of blood. In "Dialogue", specifically, we are told that the ruler "celebrates / with the champagne of blood" (Eaters 39). Dark images pulsate in "The concert of cannibals" and "Your excellency". In the former, the land is described as "where corpses sprouted / into gravestones of memorial poetry", whereas the latter tells of vultures hovering "over the carcass / of the nation" (Eaters 56, 59). The use of animal imagery is a motif in Okpanachi's poetry, and this clearly inflates the viciousness of the state. The conflation of the politicians with beasts is to deny them subjectivities and sensibilities, thereby presenting them as predatory. Politicians are therefore "a pack of wolves" that "trade / with our blood" (Eaters 67).

There are sparse representations of the funereal in From the Margins of Paradise. Notwithstanding, the theme of death remains evident in "Love me and leave me", a satirical poem chronicling the ruler's "brutal rituals of love":

Love me your own way

Tie me to the stake

To celebrate my free will

Give me the liberty that is a chain

And spell my freedom

In the colour of death

Hate me to love me

Torture me to love me more

Burn me to cherish me

Kill me to give life. (Margins 29)

The vile triumphalism of the political cabal finds accent in "Children of the night" in the collection From the Margins of Paradise. Members of this class boast:

We murder in the name of democracy

We plunder in the name of austerity

We massacre in the name of security

We maim in the name of justice

$[\ldots]$

We pillage the land

Until you become paupers

We are the predators

You forever remain preys 
We are the bloodsuckers

The vampires of the new nation. (Margins 56)

Images of graves, corpses, and cemetery in this collection appear for the first time in "When they die". It is a poem about the pomp that occasions the funerals of politicians. Grave is mentioned four times, caskets, and coffins twice, and cemetery once, all pointing out the fact that the ruler himself cannot escape death even when flown "on a private jet / in a million caskets of delight" (Margins 58). The image of death is pronounced in "The legion of cain," as it describes how politicians tend to "toy with life/ to remain immortal" (Margins 62). Though the biblical reference-the story of Cain and Abel—is not developed, killing is implied in the stanza below:

They write the laws

With golden edges of the sword

In the blood of the innocent

Across the throne

$[\ldots]$

Here the gallows are tall

Here the play of the dead

Has a silent audience

Here your rights die before you. (Margins 62)

The image of the vampire is recognisable in "A dirty tea party", though more horrid images are presented subsequently:

Slabs for the unborn

A headstone for the foetus

$[\ldots]$

We vote in the ballot of graves

In democracy of coffins

$[\ldots]$

And bury people in shrouds

Of ballot papers with their legs

Jutting out of the graves. (Margins 104) 
Not even babies and the unborn are exempted from the brutality of the state and its repressive apparatuses, and so Okpanachi's poetry provides us with a lens, even if darkly, through which to interrogate the ways in which death has structured the post-military reality of many Nigerians. For the poet, democracy has only created a condition in which politics has become the work of death (see Mbembe 16).

Music of the Dead opens with "A Long Silence", a prose poem which presents in dense rhythm a montage of uncanny scenes of "an age stranger than time and chameleon" (Music 1). In this strange age, the news of people dying is common, but the causes of their deaths might seem ludicrous were it not strange. For instance, "the common news" in this prose poem is that "somebody dies from sneezing, another one from seconds of coughing, one from being shot several times by an invisible bard of death, yet another from laughter and one after a feather carried by the breeze hit him" (Music 1-2).

Due to the commonness of death in the land, the poet bemoans the fact that "the graveyards are full; the country is a cemetery in the hands of the dead" (Music 2). The bard of death, personified by the ruler, and the shepherds his minions, have ushered in an age where it is "so easy to die" (2). Aside from the plethora of horrific imagery, the poet further uses words signifying death such as "extinction", "drowning", "killing", and "immolation". The poem prefaces the kind of imagery one will mainly come across in the collection-imagery denoting various acts of dying.

"Democracy of Cemetery" tells of a child who dies "[f]rom gunshot wounds/from the bullet(ing)" of the "local council dog" (Music 4). Its use of the funerary imagery of "blood", "shroud," "grave", "pall", and "undertaker" restates the commonness of death in the body politic, as foreshadowed in the opening poem. The sequence of poems in "Dogs and Angels 1-111" narrate the manifestations of brutality orchestrated by the ruler and his "butchers" and "dogs" (Music 10-1). Death is evoked in the poem, but more striking is the poet's appropriation of a biblical narrative to amplify tragic experiences:

A male child must perish

Rivers must run blood

Vermin must take over the land

So Pharaoh must be born

Pharaoh must be born again

To extinguish rights and mind

To beatify people with blood

On gallows of love. (Music 9-10)

The above poem references the plagues of Egypt, ten calamities that occurred during the reign of Pharaoh. Here, a similar tyrant is born anew, his reign no less brutal than 
his biblical counterpart. The poet tells us that the tyrant is known to "spill rose blood as souvenir / to the land of cemetery" (Music 11). The country, though depicted as a cemetery, becomes the "treasured garden" of the new Pharaoh who, rather ironically, chooses to sequester himself in the Rock, fenced in by "graves becoming hedges" (Music 12). The Rock here operates as a synecdoche for Aso Rock, the presidential villa in Nigeria, where the ruler deems himself safe from the "reach of death" (Music 12).

Death is implied in "The Forerunner", a poem portraying the ruler's perversity as he turns the world on its head and leaves behind a trail of death (Music 18). The ruler's perversity is further elaborated in "Scoundrels", and we find that the ruler has inaugurated a "new game of war", in which he is wont to "put babies on death row" (20-1). In the rule of scoundrels, not even babies and children are spared from terror and violence. The image of death recurs in "Spider", and again terror is evoked in the aliases by which the ruler is addressed: "the mastercraft of fear", the "sorcerer [...] [who] pulps people / to disinfect his hands with [their] blood" (Music 22 , 23). The image of the sorcerer-ruler "turn[ing] children to jerboas / hunted by snakes" (Music 22) is ghastly (jerboas are hopping desert rodents found predominantly in northern Africa). Grisly images teem in "The Sharks", a poem that opens with "Crows have inherited / the blood of children" (Music 26). The poem forewarns of danger that both children and the unborn face. The political class is represented as the "undertakers of power" that presides over the "democratic coffins" and voting is tangentially described as "to drown" in "the high seas" (Music 26, 27), after the following grisly image:

We have dug 150 million graves

For people to vote with their bodies

Submitting to the undertakers of power. (Music 26)

The theme of death finds some resonance in "Black Flower", a poem which recounts the "seasons of massacre" orchestrated by the political cabal who has "death written on their tongues" (Music 28). In the seasons of massacre, the undertakers of power are found to be "play[ing] solitaire with corpses" (Music 28-9). A desolate city is portrayed in "Without a Name" where "human faces hanging/Upside down sprout everywhere" (Music 30). This poem echoes T. S. Eliot's poem "The Journey of the Magi", and the city where the Magi visit typifies what Mbembe calls death-worlds, a kind of "social existence in which vast populations are subjected to conditions of life conferring upon them the status of living dead" (Mbembe 40). In this city, "blood rains from the sky", "vultures feast on carcasses", and "children drink/ spices of hemlock" (Music 30-1). There is indeed no innocence, no beauty, no redemption, but depravity, ugliness, devastation - and of course death in this necropolis. A biblical reference is also utilised to nuance its narrative depth: "The star of the Magi trails blood/Splashed across the sky" (Music 30). What is recounted in "Without a Name" is something 
mournful: death, not birth, is presaged by the star of the Magi. Moreover, the biblical Magi are heralds of good news, but in the poem, they are harbingers of death, seeking not a new-born king but "a mangled messiah" (Music 30). The penultimate line consolidates on the funerary: "Hearses carry casks of musk/ To the graveyards for the predators / Who nail roses on the Cross" (Music 31).

Emmanuel Obiechina contends that the poet must "become the sensitive needle that probes and locates our emotional traumas, our anxieties, elations and fears, no less than our hopes and aspirations" (211). There is no artistic creed that demands that every poet be involved in social activism or political revolution, although there is something remarkably altruistic and noble about a poet choosing to identify with the collective struggle of the people against authoritarian forces. Okpanachi employs his art to decry statist hegemonic systems authorising death. He explores one of such systems in "The Constitution". The constitution referred here is not the supreme document encapsulating the people's hopes and aspirations, but the type that "will write the codes / of pains" and "punish with laws written by swords" (Music 68). It is constructed to inflict more hardship on the already impoverished people, while herding them closer to their death. It also ensures that anyone who defies its stipulations will have "their faces marked with red-hot iron" (Music 68). This fiery image referenced in the opening poem alludes to the branding of people's faces (with the mark of the beast, perhaps) during the reign of the biblical antichrist. We can make out the sense of glee exhibited by the makers of this constitution in "The Hawkers of Blood". As the heirs of the "primitive gods of war", they celebrate death and declare that

\section{Mass murder is our carnival}

Death sits between our eyes seeing

The world through the lens of war. (Music 77)

The scenes recreated here recall the devastation in certain parts of Nigeria masterminded by the Islamist terrorist group Boko Haram. Their attacks have resulted in the deaths of thousands of citizens. The briefest poem in the entire collection is "The News", and it enumerates various representations of dying such as "Maiming / Massacre (mass acre) / Murder/Mangle / Mutilate" (Music 78). Gog and Magog are identified in the Bible as two nations that will wage an apocalyptic battle against the children of Israel. As a result, there will be a slaughter so great it would take months to have all the dead buried completely. The poet only appropriates these biblical names but not the narrative in titling his poem, "The Gog and Magog". Although the poet barely hints at war, he peppers the poem with a few dark images. The politicians are described as murderous, their "paunches are / the mass graves of the people" and they "play ninepins with human heads" (Music 80-1).

Irony and satire are strong features of Okpanachi's poems, and he employs them 
effectively in "You the People's Choice", a poem satirizing the ruler as Pharaoh. Intolerant of opposition, his reign marks "the season of madness". We learn that he "Lick[s] their blood off [his] fingers / And eat[s] their flesh as right" (Music 85). It is not only the state that the poet criticises, for he also charges against everyone who is complicit in the dehumanisation of the citizenry. He calls them the "new butchers" in "My Father's House", a poetic parody of Our Lord's Prayer or the Pater Noster, one of the most-widely spoken prayers in the world. In this poem, the poet implicates the "professional murderers" before God:

The judge who miscarries justice

The hangman who unfurls the noose

The tailor who sews the shroud

The butcher who stitches the flesh

The list runs on:

The carpenter who makes the coffins

The undertaker who closes the graves

The executioners of mourners of the beloved

The priest who lies against God

The poet whose tears are the streams of treason. (Music 92)

The atrocities of these butchers are set in relief in "King of Cemetery". The poem's depiction of events may well be the most bizarre in the collection, for we are told that the butchers "rape the dead in their graves", while ensuring that those "they bury alive" do not leave the cemetery (Music 96).

Charles Nnolim argues that the postcolonial writer must take a stand for or against power, for she cannot afford to stand by and watch her land consumed by forces of misrule (223). In his poetry, Okpanachi fulfills what Breyten Breytenbach expects of the writer that he be the questioner, the implacable critic, and the exponent of the aspirations of the people (166). Okpanachi, in an interview I conducted with him in 2014, declared that "Poetry is a veritable voice of dissent against anything that works against human rights, freedom and humanity" (n. p.). This underwrites and sums up his pact with society, his artistic vision. His fascination with funereal imagery is not that he delights in the horrific, but that he is attempting to expose the spectrality of death and to focus the reader's attention on the morbidity of postcolonial experiences. He denounces unbridled pursuit of power and its abuse, while revealing that although the nation is no longer brutalised by military junta, it nonetheless remains in a stranglehold.

\section{Conclusion}

Taken together, Musa Idris Okpanachi's The Eaters of the Living, From the Margins of Paradise, and Music of the Dead signal the extent to which Nigeria has foundered in its 
democratic journey. His opus offers us a way to reflect on questions of mortality and citizenship in a world haunted by death. Death has become so banal that precarity marks the life of citizens. The citizens of this macabre postcolonial world may have only succeeded in replacing one set of death-merchants with another, since the civilian government seems even more deadly and exploitative than the military was. It is the proclivities of the political class to despoil and destroy rather than nurture and salvage that Okpanachi has captured rather too trenchantly, even if grimly. This class is therefore portrayed as non-humans, a metaphor that is typically associated with African tyrants. By employing images both dark and haunting in his poetry, the poet intends to alert the people against the danger of inertia, lest they be left with "a country of cemetery." Okpanachi's tones may be ironic, insistent, and cynical—but underneath all of this is the poet's unstinting commitment to the democratic struggle of the postcolony.

\section{Acknowledgements}

I would like to acknowledge the insightful comments of the anonymous reviewers. I am furthermore grateful to Professors Onyemaechi Udumukwu, Lahoucine Ouzgane, Albert Braz, Isidore Diala, Nduka Otiono, Egya Sule, and my friend Abubakar S. Abdulkadir for encouragement.

\section{Works Cited}

Aboh, Romanus. "Modality as a Discourse Strategy in New Nigerian Poetry." Journal of Nigerian Studies vol. 1, no. 2, 2012, pp. 1-18.

Achebe, Chinua. The Trouble with Nigeria. Heinemann Educational, 1983.

Breytenbach, Breyten. "The Writer and Responsibility," African Literature: An Anthology of Criticism and Theory. Eds. Tejunola Olaniyan and Ato Quayson. Blackwell, 2007, pp. 165-71.

Diala, Isidore. "Bayonets and the Carnage of Tongues: The Contemporary Nigerian Poet Speaking Truth to Power." The Journal of Commonwealth Literature, vol. 52, no. 1, 2015, pp. 1-23. DOI: https://doi. org/10.1177/0021989415575800.

Mbembe, Achille. "Necropolitics." Public Culture, vol. 15, no. 1, 2003, pp. 11-40.

Nnolim, Charles. Issues in African Literature. Malthouse, 2010.

Obiechina, Emmanuel. Language and Theme: Essays on African Literature. Howard U P, 1990.

Okpanachi, Musa. The Eaters of the Living. Kraft, 2007. . From the Margins of Paradise. Kraft, 2012. . Music of the Dead. Origami, 2016. and Umezurike, Uchechukwu Peter. "Uche Peter Umez interviews Poet Musa Idris Okpanachi." Africa in Words. 19 Dec. 2013. https://africainwords.com/2013/12/19/qa-uche-peter-umez-interviewspoet-musa-idris-okpanachi/. Accessed 30 Jun. 2016.

Okunoye, Oyeniyi. "Writing Resistance: Dissidence and Visions of Healing in Nigerian Poetry of the Military Era." Tydskrif vir Letterkunde vol. 48, no.1, 2011, pp. 64-85. https://journals.assaf.org.za/tvl/ article/view/2337.

Sule, Egya. "Imagining Beast: Images of the Oppressor in Recent Nigerian Poetry in English." The Journal of Commonwealth Literature vol. 46, no. 2, 2011, pp. 345-58. https://doi.org/10.1177/0021989411404996.

. "Poetry as Dialogue: A Reading of Recent Anglophone Nigerian Poetry." E-Cadernos Ces, no. 12, 2011, pp. 75-92. https://journals.openedition.org/eces/697. 